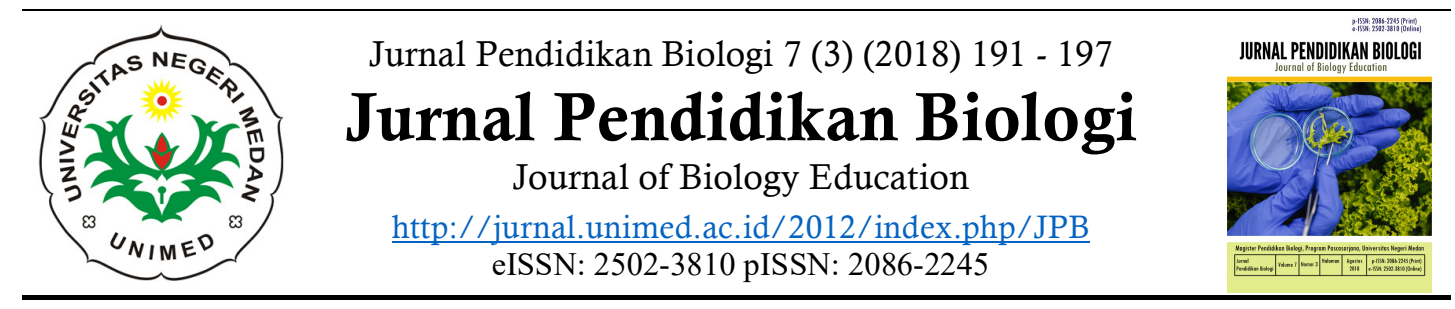

\title{
Peningkatan Hasil Belajar Melalui Model Pembelajaran Inkuiri Laboratorium pada Materi Asam, Basa, dan Garam di Sekolah Menengah Pertama
}

\author{
Syofia Yohana \\ Sekolah Menengah Pertama Negeri 1 Percut Sei Tuan, Jalan Besar Tembung Gang \\ Pendidikan Kabupaten Deli Serdang, Sumatera Utara, Indonesia \\ Korespondensi: syofiayohana@gmail.com
}

DOI: https://doi.org/10.24114/jpb.v7i3.10871

\begin{abstract}
The problem faced in this study is the low science learning outcomes in material related to chemistry. The purpose of this study was to determine the improvement of student learning outcomes through the Laboratory Inquiry learning model on acid, alkaline, and salt material in class VII of SMP 1 Percut Sei Tuan Tahun. Action research was conducted in class VII of SMP Negeri 1 Percut Sei Tuan with a total of 32 students. The research took place in 2 cycles by expressing four stages in each cycle, namely: the stages of planning, implementation, observation, and reflection. Analysis of research data in the form of quantitative and qualitative data which is the student learning outcomes (pre-test and post-test) and the results of observations of students' skills utilizing percentage, namely by calculating the increase in student mastery learning individually. The results of the first cycle test, there were 17 students (53.13\%) had achieved mastery learning while 15 students (46.87\%) had not achieved mastery learning. After it was found that there was an increase, it continued to give action in the second cycle. Then the results of the second cycle test were found to have a substantial increase in the number of students completing, namely from 32 students. It turned out that 28 students $(87.50 \%)$ had achieved mastery learning, only four students $(12.50 \%)$ had not reached completeness in learning. Students' skills in conducting practicum have increased significantly. Based on the results of the first cycle test and the second cycle test, it can be concluded that the Laboratory Inquiry Learning Model on Acid, Base, and Salt material can improve the learning outcomes of junior high school students.
\end{abstract}

Keyword: Learning outcomes, Laboratory Inquiry, acids, bases, and salt

\section{PENDAHULUAN}

Ilmu Pengetahuan Alam (IPA), merupakan pondasi bagi perkembangan ilmu pengetahuan dan teknologi pada masa yang akan datang. Ilmu Pengetahuan Alam bukan hanya kumpulan pengetahuan yang berupa fakta, konsep, dan prinsip. Pendidikan IPA menekankan pada pemberian pengalaman secara langsung dalam arti bekerja ilmiah sebagai lingkup proses. Lingkup proses berkaitan erat dengan konsep, maka bekerja ilmiah adalah mengintegrasikan isi ilmu pengetahaun alam ke dalam kegiatan-kegiatan pembelajaran yang membekali pengalaman belajar siswa secara langsung.

Kenyataan di lapangan dewasa ini, proses pembelajaran IPA di sekolah-sekolah masih belum sesuai dengan harapan. Masih 
banyak guru yang masih kurang kreatif dalam menggunakan berbagai media pembelajaran karena berbagai alasan, seperti faktor penyediaan alat dan bahan, dana, dan waktu. Pengamatan pada metode pembelajaran IPA di sekolah selama ini menimbulkan dugaan, bahwa siswa kurang memiliki pengalaman, kurang mendapat kesempatan untuk mengalami sendiri gejala-gejala alam yang harus mereka pelajari dan kuasai. Ilmu Pengetahuan Alam tidak boleh dipisahkan dari karakteristik alamiahnya. Minat yang timbul dari keheranan, rasa ingin tahu dan kekaguman, menjadi modal yang amat besar bagi siswa untuk mempelajari dan memperdalam Ilmu pengetahuan Alam kelak di kemudian hari. Dalam lingkup proses tersebut siswa perlu dibantu untuk mengembangkan sejumlah kemampuan untuk memahami gejala alam. Salah satu kemampuan yang perlu dikembangkan adalah kemampuan inkuiri (Amin, 1987).

Inkuiri sangat menuntut keaktifan siswa dalam belajar. Inkuiri dapat meningkatkan penguasaan sains siswa, kreatifitas siswa, dan siswa menjadi terampil dalam memperoleh dan menganalisis data (Joyce \& Weil, 1972; Schlenker \& Schlenker, 2000). Hodson (1996) menyatakan bahwa pembelajaran berbasis laboratorium meningkatkan perkembangan siswa. Berdasarkan pandangan tersebut, dapat disintesis suatu pendekatan yang digunakan dalam penelitian ini yaitu pendekatan inkuiri laboratorium. Dalam pendekatan inkuiri laboratorium, konsep-konsep yang dipraktikumkan dirancang sedemikian rupa sehingga relevan dengan kehidupan seharihari siswa.

Model Pembelajaran Inkuiri menekankan pada pentingnya kegiatan-kegiatan ilmiah yang dapat mengarahkan siswa untuk menemukan konsep-konsep baru. Pendekatan inkuiri yang dikembangkan menekankan pada pemaknaan fenomena kimiawi yang sudah dikenal oleh siswa SMP. Banyak masalah IPA terutama aspek kimia sehari-hari yang terjadi di masyarakat.

Siswa dikelas VII SMP Negeri 1 Percut Sei Tuan dalam proses pembelajaran IPA kurang termotivasi, kurang terampil dalam melakukan praktikum, sehingga hasil belajar siswa dikelas VII pada pelajaran IPA masih rendah, sehingga perlu adanya Penelitian Tindakan Kelas guna meningkatkan hasil belajar dan meningkatkan keterampilan siswa dalam pelaksanaan praktikum. Penelitian yang dilakukan diharapkan akan memberikan kontribusi yang baik terhadap pendidikan di Sekolah Menengah Pertama.

\section{METODE PENELITIAN}

Penelitian Tindakan Kelas ini dilaksanakan di Kelas VII SMP Negeri 1 Percut Sei Tuan, Kecamatan Percut Sei Tuan, Kabupaten Deli Serdang, Sumatera Utara. Penelitian ini berlangsung sebanyak 2 siklus. Subjek dalam penelitian ini adalah siswa kelas VII yang berjumlah 32 orang siswa. Adapun karakteristik siswa cenderung sama dengan kelas lainnya ditinjau dari aspek prestasi belajar, jumlah siswa, usia siswa dan tingkat sosial ekonomi. Alasan pemilihan siswa kelas VII sebagai subjek penelitian karena tingkat pencapaian hasil belajar masih banyak yang belum mencapai ketuntasan belajar sesuai dengan kriteria ketuntasan minimal (KKM). Desain penelitian yang digunakan berbentuk siklus yang mendaur ulang empat kegiatan pokok yang berupa perencanaan, pelaksanaan, pengamatan, dan refleksi. Pengumpulan data dilakukan dengan melakukan tes. Penyusunan tes dapat dilakukan berdasarkan materi yang dibelajarkan dan sesuai dengan kompetensi dasar. Penggunaan tes ini untuk menjaring data peningkatan hasil belajar dan karakter siswa khususnya penguasaan materi yang diajarkan dengan 
menggunakan model pembelajaran inkuiri laboratorium.

Data pada penelitian ini dianalisis untuk mengetahui peningkatan hasil belajar dan keterampilan siswa saat praktikum pada materi asam basa dengan menggunakan model pembelajaran inkuiri laboratorium. Data yang diperoleh dari setiap siklus yang dilaksanakan dianalisis secara deskriptif dengan menggunakan teknik persentase untuk melihat tingkat kecenderungan yang terjadi pada setiap kegiatan pembelajaran yang dilakukan. Peningkatan hasil belajar siswa dapat diukur ketuntasannya berdasarkan KKM yang sudah ditetapkan. Untuk memudahkan tingkat kategori keberhasilan siswa maka diambil rata-rata siswa. Dari rata-rata tersebut diolah berdasarkan persentase (Arikunto, 1989).

\section{HASIL DAN PEMBAHASAN}

Hasil penelitian berupa proses pembelajaran tindakan kelas melalui model pembelajaran inkuiri laboratorium. Kondisi awal bahwa nilai ulangan siswa masih rendah, yang mencapai ketuntasan belajar masih termasuk kategori sangat kurang, hasil tes awal, dari 32 orang siswa yang menjadi subjek dalam penelitian ini, ternyata hanya 8 orang siswa (25\%) yang sudah mencapai ketuntasan belajar materi asam basa, sedangkan 24 orang siswa (75\%) belum mencapai ketuntasan dalam belajar.

Kegiatan siklus I dilakukan guna meningkatkan hasil belajar siswa dengan menggunakan tes awal sebagai pembanding untuk melihat peningkatan hasil belajar dengan menggunakan Model Pembelajaran inkuiri laboratorium pada materi asam basa dan garam. Berdasarkan data hasil siklus I di atas dapat dilihat bahwa hasil belajar siswa dalam pembelajaran materi asam basa dan garam ternyata mulai meningkat. Hasil belajar pada siklus I ini mengalami peningkatan dibanding hasil tes awal. Untuk lebih jelas mengenai persentase ketuntasan belajar siklus I dapat dilihat pada Tabel 1.

Tabel 1. Hasil tes siklus I

\begin{tabular}{cccc}
\hline No & Keterangan & Jumlah Siswa & Persentase \\
\hline 1 & Tuntas & 17 & $58,13 \%$ \\
2 & Tidak Tuntas & 15 & $46,87 \%$ \\
\hline
\end{tabular}

Berdasarkan Tabel 1 dapat dinyatakan bahwa analisis hasil belajar pada materi asam,basa dan garam pada tes siklus I terdapat 17 orang siswa(53,13\%) sudah mencapai ketuntasan belajar, sedangkan 15 orang siswa $(46,87)$ belum mencapai ketuntasan belajar. Ternyata hasil siklus I lebih baik dari tes awal (pre-test) walaupun belum maksimal, sehingga masih perlu dilanjutkan ke pelaksanaan siklus II. Persentase hasil observasi keterampilan siswa saat melakukan praktikum dilaboratorium disajikan pada Tabel 2.

Tabel 2. Persentase hasil observasi keterampilan siswa di laboratorium

\begin{tabular}{clrc}
\hline No & \multicolumn{1}{c}{ Aspek yang diobservasi } & Jumlah & Persentase \\
\hline 1 & $\begin{array}{l}\text { Ketrampilan siswa dalam menuangkan larutan dari satu wadah ke } \\
\text { wadah lainnya }\end{array}$ & 20 & $62,50 \%$ \\
2 & $\begin{array}{l}\text { Keterampilan siswa dalam meneteskan/menggunakan/ mengambil } \\
\text { larutan/ indikator }\end{array}$ & 22 & $68,75 \%$ \\
3 & Keterampilan siswa dalam mencuci pipet tetes & 23 & $71,86 \%$ \\
4 & Keterampilan siswa dalam mengukur volume larutan & 18 & $56,25 \%$ \\
5 & Keterampilan siswa dalam mengkonversi larutan & 15 & $46,86 \%$ \\
6 & Keterampilan siswa dalam mengamati perubahan warna & 21 & $65,63 \%$ \\
\hline
\end{tabular}


Keterampilan siswa dalam melaksanakan praktikum mempunyai tingkat yang berbeda. Pada siklus I, guru pengamat mendapatkan 20 siswa $(62,50 \%)$ terampil dalam menuangkan larutan dari satu wadah ke wadah yang lain, 22 siswa $(68,75 \%)$ terampil dalam meneteskan/ menggunakan/ mengambil larutan/ indikator, 23 siswa $(71,86 \%)$ terampil dalam mencuci pipet, 18 siswa $(56,25 \%)$ terampil dalam mengukur volume larutan, 15 siswa $(46,86 \%)$ terampil dalam mengkonversi larutan dan 21 siswa $(65,63 \%)$ yang terampil dalam mengamati perubahan warna.

Setelah diadakan refleksi dan evaluasi, guru sebagai peneliti mendapatkan beberapa kelemahan yang dapat mengganggu situasi pembelajaran., ini merupakan masukkan untuk perbaikan. Selanjutnya hasil belajar siklus I ini digunakan sebagai acuan dalam memberikan tindakan pada siklus II untuk mengatasi kesulitan siswa dalam memahami materi asam basa dan garam. Hasil belajar siswa pada tes siklus I ini masih rendah walaupun ada sedikit peningkatan, hal ini terlihat dari nilai rata-rata yang diperoleh siswa yaitu 62 .

Setelah melakukan refleksi pada tindakan siklus I, maka peneliti melanjutkan penelitian ini ke siklus II. Kelemahan pada siklus I akan diperbaiki pada siklus II setelah berdiskusi dengan pengamat tentang solusi untuk memperbaiki kelemahan pada siklus I, Pelaksanaan siklus II merupakan perbaikan terhadap kelemahan pada siklus I dengan mempertahankan serta meningkatkan keberhasilan yang telah dicapai pada siklus I.

Pada tahap ini peneliti membuat alternatif pemecahan masalah untuk mengatasi kesulitan siswa dalam pembelajaran materi asam, basa dan garam. Perencanaan ini dilakukan khususnya pada siswa yang masih memperoleh nilai rendah. Pada siklus II dalam kegiatan ini peneliti merefleksi dan mengevaluasi semua tahap kegiatan yang telah dilakukan mulai dari pelaksanan kegiatan tindakan hingga observasi dan diperoleh data hasil postes ketuntasan belajar seperti disajikan pada Tabel 3 .

Tabel 3. Data Hasil Tes Siklus II

\begin{tabular}{|c|c|c|c|}
\hline No & Keterangan & Jumlah Siswa & Persentase \\
\hline 1 & Tuntas & 30 & $(93,75 \%)$ \\
\hline 2 & Tidak Tuntas & 2 & $(6,25 \%)$ \\
\hline
\end{tabular}

Berdasarkan Tabel 3 dapat dilihat bahwa hasil belajar siswa pada siklus II pada materi asam, basa, dan garam ternyata hasilnya lebih meningkat bila dibandingkan dengan siklus I, dan hasilnya sudah cukup maksimal. Hasil data observasi yang dilakukan oleh guru pengamat saat berlangsungnya praktikum di laboratorium disajikan pada Tabel 4.

Tabel 4. Data hasil observasi siklus II

\begin{tabular}{|c|c|c|c|}
\hline No & Aspek yang diobservasi & Jumlah & Persentase \\
\hline 1 & $\begin{array}{l}\text { Ketrampilan siswa dalam menuangkan larutan dari satu wadah ke } \\
\text { wadah lainnya }\end{array}$ & 25 & $78,12 \%$ \\
\hline 2 & $\begin{array}{l}\text { Keterampilan siswa dalam meneteskan/menggunakan/mengambil } \\
\text { larutan/indicator }\end{array}$ & 28 & $87,50 \%$ \\
\hline 3 & Keterampilan siswa dalam mencuci pipet tetes & 29 & $90,62 \%$ \\
\hline 4 & Keterampilan siswa dalam mengukur volume larutan & 24 & $75 \%$ \\
\hline 5 & Keterampilan siswa dalam mengkonversi larutan & 23 & $71,87 \%$ \\
\hline 6 & Keterampilan siswa dalam mengamati perubahan warna & 21 & $65,63 \%$ \\
\hline
\end{tabular}


Pada siklus II terlihat tingkat keterampilan siswa mengalami peningkatan. Guru pengamat mendapatkan 25 siswa $(78,12 \%)$ terampil dalam menuangkan larutan dari satu wadah ke wadah yang lain, 28 siswa $(87,50 \%)$ terampil dalam meneteskan/ menggunakan/ mengambil larutan/ indikator, 29 siswa $(90,62 \%)$ terampil dalam mencuci pipet, 24 siswa $(75 \%)$ terampil dalam mengukur volume larutan, 23 siswa $(71,87 \%)$ terampil dalam mengkonversi larutan dan 21 siswa $(65,63 \%)$ yang terampil dalam mengamati perubahan warna.
Mengaktifkan siswa untuk terlibat dalam setiap kegiatan pembelajaran diperlukan dua kali pertemuan. Proses pelaksanaan siklus II dimulai dari tahap perencanaan, tindakan, observasi dan refleksi. Berdasarkan hasil refleksi siklus II di atas, ternyata masih ada yang belum mencapai ketuntasan dalan belajar materi asam, basa dan garam. Menurut analisis peneliti hal ini disebabkan siswa tersebut masih memerlukan tambahan waktu dan kurangnya mereka untuk berdiskusi dengan siswa lainnya. Deskripsi data yang diperoleh setelah melakukan penelitian tindakan kelas disajikan pada Tabel 5

Tabel 5: Deskripsi Data Hasil Belajar Kelas VII-2 SMPN 1 Percut Sei Tuan

\begin{tabular}{cccccc}
\hline No & Hasil Tes & Jumlah Siswa & Persentase & Nilai (Mean) & Keterangan \\
\hline 1 & Awal & 8 & $25 \%$ & 58,44 & Tidak Tuntas \\
2 & Siklus I & 17 & $53,12 \%$ & 67,71 & Tidak Tuntas \\
3 & Siklus II & 30 & $93,75 \%$ & 75,00 & Tuntas \\
\hline
\end{tabular}

Pada Kondisi Awal, siswa sangat sulit memahami materi Asam Basa, dan garam karena mereka hanya mendapatkan penjelasan saja tanpa menunjukkan contohnya dan melakukan praktikum. Pengaruh pemberian contoh nyata di dalam kehidupan seharihari, dengan melakukan praktikum di laboratorium pada materi asam basa dan garam tersebut, membuat siswa termotivasi mengikuti pembelajaran. Pada siklus I terlihat jelas peningkatan hasil belajar yang signifikan walaupun nilai ketuntasan 70 masih sedikit yang bisa mencapainya.

Hasil siklus I menunjukkan bahwa jumlah siswa yang sudah mencapai ketuntasan belajar masih rendah. Hal ini perlu dicermati peneliti, peneliti harus bisa memahami perbedaan tingkat pemahaman siswa. Analisis hasil belajar siswa pada siklus I masih lebih baik dari tes awal walaupun hasilnya belum maksimal, sehingga perlu dilanjutkan pada pelaksanaan siklus II, hal ini dapat dilihat dari kesulitan siswa dalam memahami materi asam basa dan garam.

Tes awal yang diberikan kepada siswa sebelum menentukan perencanaan sangat berguna untuk mengetahui perkembangan hasil belajar siswa sebelum diadakan pembelajaran dengan menggunakan Model Pembelajaran inkuiri laboratorium. Pelaksanaan tindakan pada siklus I dilakukan untuk mendapatkan hasil yang cukup baik sehingga tercapai ketuntasan belajar yang lebih baik. Sebagai besar siswa belum mencapai ketuntasan belajar serta rendahnya hasil belajar siswa, hal ini dapat dilihat pada data sebelumnya. Hasil

belajar siswa pada siklus II ternyata hasilnya maksimal, hal ini dapat dilihat dari banyaknya siswa yang sudah memahami materi asam, basa dan garam, sebagian besar dari siswa kelas VII sudah mencapai nilai ketuntasan belajar ( di atas 75 ). Jumlah siswa yang mencapai ketuntasan sebanyak 30 orang siswa menunjukkan pencapaian yang sangat signifikan walaupun masih ada 
2 orang siswa yang belum mencapai ketuntasan, hal ini disebabkan kurang aktifnya siswa tersebut dalam pembelajaran.

Berdasarkan hasil penelitian berupa kegiatan awal, kegiatan lanjutan berupa tindakan pada siklus I dan siklus II dalam proses pembelajaran dengan menggunakan Model Pembelajaran inkuiri laboratorium, ternyata telah diperoleh peningkatan hasil belajar yang sangat signifikan. Hal ini dapat dilihat dari meningkatnya nilai Persentase Ketuntasan Klassikal (PKK) serta nilai ratarata hasil belajar siswa. Hasil tes siklus II ternyata nilai PKK yang diperoleh siswa kelas VII SMP Negeri 1 Percut Sei Tuan TP. 2014-2015 telah mencapai 93,75\%. Apabila nilai PKK lebih besar dari 85\% maka telah tercapai ketuntasan belajar klassikal dan meningkatnya nilai Persentase keterampilan siswa dalam melaksanakan praktikum di laboratorium.

Integrasi lingkungan dan pembelajaran sangat penting untuk dilakukan (Cobern \& Aikenhead, 1997). Kegiatan laboratorim berbasis inkuiri dapat meningkatkan hasil belajar siswa SMA dan Mahasiswa (Cunningham, et al., 2006). Menurut Ketpichainarong, et al. (2010), kegiatan laboratorium berbasis inkuiri dapat meningkatkan keaktifan mahasiswa. Kegiatan praktikum akan membina sikap ilmiah siswa (Nurrohman, 2007). Perlu dilakukannya evaluasi perilaku dan pemikiran tentang sikap ilmiah siswa untuk dapat menumbuhkan sikap ilmiah (Khan, 2012).

\section{KESIMPULAN}

Berdasarkan data hasil penelitian yang sudah dilakukan peneliti, maka diperoleh kesimpulan bahwa penggunaan Model Pembelajaran Inkuiri Laboratorium dapat meningkat hasil belajar IPA pada materi Asam Basa dan garam dapat meningkat keterampilan siswa dalam melakukan praktikum di laboratorium di kelas VII SMP Negeri 1 Percut Sei Tuan.

\section{UCAPAN TERIMAKASIH}

Peneliti mengucapkan banyak terimakasih kepada kepala sekolah dan rekan guru SMPN 1 Percut Sei tuan yang telah membantu dalam menyelesaikan penelitian tindakan kelas ini.

\section{DAFTAR PUSTAKA}

Joyce, B and Weil, M. (1972). Models of Teaching. Boston: Allyn and Bacon

Amin, M. (1987). Mengajarkan Ilmu Pengetahuan Alam (IPA) Dengan Menggunakan Metode "Discovery" dan "Inquiry". Jakarta: Depdikbud Dirjen Dikti Proyek Pengembangan Lembaga Pendidikan Tenaga Kependidikan.

Arikunto, S. (1989) Dasar-dasar evaluasi Pendidikan Jakarta: Rineka Cipta

Cobern, William W., and Glen Aikenhead. (1997) Cultural Aspects of Learning Science. National Association for Research in Science Teaching. Chicago, IL

Cunningham, S. C., McNear, B., Pearlman, R. S., \& Kern, S. E. (2006). Beverageagarose gel electrophoresis: an inquirybased laboratory exercise with virtual adaptation. CBE-Life Sciences Education, 5(3), 281-286.

Dimyati dan Mudjiono. (2002). Belajar dan

Pembelajaran. Jakarta: PT. Rineka Cipta.

Hodson. D. (1996). "Practical Work in School Science: Exploring Some Directions for Change". International Journal of Science Education (11). 541 - 553

Ketpichainarong, W., Panijpan, B., \& Ruenwongsa, P. (2010). Enhanced learning of biotechnology students by an inquiry-based cellulase laboratory. International Journal of Environmental and Science Education, 5(2), 169-187. 
Khan, M. (2012). The Development of Scientific Attitude in Secondary School Biology Teaching. Language in India, 12(5).

Nurohman, S. (2007). Pendekatan project based learning sebagai upaya internalisasi scientific method bagi mahasiswa calon guru fisika. Tersedia: http://staff. uny. ac. id [20 Oktober 2015].

Schlenker, R. M., \& Schlenker, K. R. (2000). Integrating science, mathematics, and sociology in an inquiry-based study of changing population density. Science Activities: Classroom Projects and Curriculum Ideas, 36(4), 16-19. 